\title{
Instructional Design Model Applied to a Virtual Guide in Clinical Simulation
}

\section{Modelo de diseño instruccional aplicado a una guía virtual en simulación clínica}

Received: 29/11/2018 | Accepted: 25/02/2019

\author{
Fanny Esperanza Acevedo Gamboa ${ }^{\mathrm{a}}$ \\ Pontificia Universidad Javeriana, Colombia \\ Juan Carlos Díaz Álvarez \\ Universidad Nacional de Colombia, Colombia \\ Rosa Alejandra Cajavilca Cepeda \\ Pontificia Universidad Javeriana, Colombia \\ Juan Carlos Cobo Gómez \\ Pontificia Universidad Javeriana, Colombia
}

a Correspondence: facevedo@javeriana.edu.co

\begin{abstract}
Introduction: The teaching experience of a group of teachers when teaching clinical procedures has been carried out through virtual guides prepared using instructional design models in which the pedagogical and technological pedagogical dimensions were taken into account.

Objective: To create a virtual clinical simulation guide for nursing students to have autonomous learning of a clinical-care procedure, through the application of an instructional design model.

Methods: To develop the guide it was necessary to apply the ADDIE (acronym for Analysis, Design, Development, Implementation and Evaluation) instructional design model, on which some qualitative and quantitative measurements were made.

Results: Quantitative measurements made in 159 participants between 2015 and 2016 indicated an average score of 3.99 with a standard deviation of 0.86 , which showed that the strategy used to teach the procedure with the virtual guide was effective. The qualitative evaluation assessed dimensions of satisfaction, realistic experience, confidence, motivation, technical skills and decision making, and it showed that teacher support was still required in the simulation area, which reduced the satisfaction of some participants. Likewise, one factor that was affected was communication, because the guide does not facilitate the development of this skill.

Conclusion: The ADDIE instructional model is useful for developing virtual guidelines for clinical procedures, and in its final evaluation stage allows the implementation of qualitative and quantitative research value processes to verify its effectiveness.
\end{abstract}

Keywords

instructional design model; ADDIE model; nursing education; patient simulation; guide.

\section{RESUMEN}

Introducción: La experiencia docente de un grupo de profesores en el proceso de enseñanza de procedimientos clínicos ha sido a través de guías 
virtuales elaboradas bajo modelos de diseño instruccional, en las que se tuvieron en cuenta la dimensión pedagógica y la tecnológica.

Objetivo: Construir una guía virtual de simulación clínica para que los estudiantes de enfermería tengan un aprendizaje autónomo de un procedimiento clínicoasistencial, mediante la aplicación de un modelo de diseño instruccional.

Métodos: La elaboración de la guía requirió aplicar el modelo de diseño instruccional ADDIE (sigla en inglés que significa las etapas de análisis, diseño, desarrollo, implementación y evaluación), sobre el cual se ejecutaron algunas mediciones tanto cualitativas como cuantitativas. Resultados: Las mediciones cuantitativas ejecutadas con 159 participantes entre 2015 y 2016 señalaron una calificación media de 3,99 con una desviación estándar de 0,86 , lo que determinó que la estrategia utilizada para el aprendizaje del procedimiento con guía virtual fue efectiva. La medición cualitativa valoró dimensiones de satisfacción, experiencia realista, confianza, motivación, habilidades técnicas y toma de decisiones, y con ello se evidenció que el acompañamiento docente aún se requería en el área de simulación, lo que redujo la satisfacción de algunos participantes. Igualmente, un factor que se afectó fue la comunicación, porque la guía no facilita el desarrollo de tal habilidad.

Conclusión: Es útil el modelo de diseño instruccional ADDIE para la elaboración de guías virtuales de procedimientos clínicos y en su etapa final de evaluación permite implementar procesos valorativos investigativos de corte cualitativos y cuantitativos, para verificar su efectividad.

Palabras clave

modelo de diseño instruccional; modelo ADDIE; educación en enfermería; simulación de paciente; guía.

\section{Introduction}

In Colombia, nursing students face multiple realities in human care, derived from nursing care. They intervene the human body, manipulating tissues or organs and establishing some type of action to provide health care. The effectiveness of the procedures will depend on the training, which takes place in simulation centers where they acquire a certain degree of skill and dexterity; in addition, there they understand the risks they face from deontological and teleological areas related to the procedure. In this regard, it is stated that: "The use of simulators should not only focus on practicing manual procedures, but also generate a learning environment that includes the development of other skills such as communication, reflection, critical thinking, decision-making and the consideration of the patient as a complex human being" (1).

Educational innovation with simulators facilitates interactive learning based on information and communications technology (ICT), which combine information technology, telecommunications, electronic media, interdisciplinary work with experts and the creation of teaching materials, which should incorporate attractive technologies to facilitate teaching and, consequently, improve patient care (2).

The learning of nursing disciplinary contents in virtual environments is an important element in the teaching and learning process (3). The technological resources used illustrate nursing procedures realistically, while facilitating acceptance and effectiveness in learning; therefore, e-learning uses multimedia technologies and the Internet to promote and improve its quality (4).

The scientific literature regarding the application of technologies in education shows the term educational design or instructional design appears, in which the needs and the learning environment are analyzed, the training objectives are defined and the more appropriate resources are chosen, taking into account the learning processes in which the contents are developed and the evaluation is designed (5).

To create the virtual guide, we used the ADDIE instructional design model, which refers to a systematic process to create virtual learning environments, to recognize thematic contents, theories of learning, instructional strategies and the technological medium that allows generating recreated environments in a mediated way, to support the knowledge-building processes (6). In turn, the techno-instructional or techno-pedagogical design concept, described by Coll (4), was taken into account, which indicates that the pedagogical and technological dimensions must be taken into account, in order to identify the strategies that facilitate the learning of contents and the technological tools pertinent to the training process. 
The objective of the present teaching experience was to build a clinical simulation virtual guide so that nursing students can autonomously learn a clinical-care procedure, through the application of an instructional design model.

\section{Background}

Since 2008, a group of researchers identified how nursing students learned clinical-care procedures, including venipuncture.

In the clinical simulation center where this research was carried out, teaching modeling was used as a strategy: small work groups were formed to show them the steps of the procedure. This activity required preparing the patient to obtain an informed consent, prepare the elements and take steps to establish venous access. For this reason, demonstrating the procedure took a long time, and its effectiveness depended on the cognitive development of the trainee and on repetition; in addition, the times and movements used exceeded the estimates, which required creating strategies to offer opportunities to learn by trial and error. As a result of this, a clinical procedural guide organized in a folder was created, showing the sequence of the steps and incorporating the possibility of developing skills with simulators.

When creating the guide, a certain degree of uncertainty was generated, since in order to design it, teacher expertise was required, and numerous steps were included. This situation led the students to rely on memory, which limited real learning. When the guide was put into operation, checklists were applied to measure and confirm the learning, and over time they were restructured based on the review of the literature and on institutional protocols.

Between 2012 and 2014, a quantitative, observational and evaluative research was conducted in the classroom with 175 nursing students. The objective was to compare the effectiveness of two didactic strategies through the clinical simulation: teaching modeling and procedural guide for the autonomous learning of venipuncture. A checklist was used to compare samples with random variables obtained in five academic periods; at the same time, we sought to evaluate the difference established in the variances of the tests applied by analyzing data with Fisher's F test. The results showed that in some academic periods, the teaching modeling strategy produced better learning results. In other academic periods, the strategy that showed the best results was the procedural guide for autonomous learning. When comparing the results, we concluded that there was no significant statistical difference in both strategies, which favored the learning of venipuncture (7).

At that time, studies on learning were encouraged, using clinical simulation with the thematic axes "perception of nursing students about the use of clinical simulation as a learning strategy" and "adherence of students to the procedural guides in clinical simulation."

The studies showed that the clinical simulation allows to repeat the procedure according to the students' needs, and helps them to gain confidence from the analysis of their mistakes. Practicing with an inanimate object allowed the transfer of knowledge to real situations with which theory and practice could be connected (8). Likewise, becoming familiar with a clinical environment develops critical thinking in decision making. In this regard, Gamboa et al. state that "students consider that clinical simulation is a useful strategy in transferability to face the challenges of real clinical practice through safe and controlled tools and scenarios" (9).

At the time, it was suggested to increase teaching support in simulated practices (9), because with the guides it was not possible to study and practice, due to limitations in time and in opportunities to repeat and learn from the mistakes (10).

The studies confirmed that there was a low adherence to the guides, in terms of student attendance and their commitment to practice them in the clinical simulation center (11); this low adherence is related to time management, work reasons and academic load. The main recommendation was: "the guides must be 
available in the University virtual platform, so that students can study them before arriving at the simulation center to practice them" (12). This allowed us to look for a model to build a virtual guide to substantiate both teacher modeling and autonomous learning, which was achieved by applying an instructional design model and the concept of techno-instructional or techno-pedagogical design.

\section{Method}

The ADDIE instructional design model refers to five moments when creating virtual learning environments: analysis, design, development, implementation and evaluation.

The analysis identifies the students, the contents and the environment that the training needs poses. The design defines the pedagogical approach and content organization and sequence. The development incorporates the creation of learning materials based on the contents set out in the design phase. The implementation refers to the execution and implementation of the teaching material with the students. The evaluation has two moments: in the first, the stages of the ADDIE process are evaluated, and in the second, specific tests are used to analyze the results of the training with the students (6).

The concept of techno-instructional or techno-pedagogical design described by Coll (4) points out that the pedagogical and technological dimensions must be taken into account. In the pedagogical dimension it is necessary to identify the recipients with their characteristics, as well as the objectives or skills of the virtual training; with this, it is possible to determine the "content development and implementation, activity planning, with guidelines and suggestions on the use of the technological tools in the development of the activities and the preparation of a plan to evaluate the processes and the results." The technological dimension involves "the selection of technological tools apropriate to the training process to be carried out, analyzing its possibilities and limitations, such as the virtual platform, software applications, multimedia resources."

\section{Application of the ADDIE instructional design model and the concept of techno- instructional design}

\author{
Analysis
}

To create the venipuncture virtual guide, the pedagogical dimension was analyzed, identifying the students that were the object of the training process, which in this case corresponded to nursing students who would be taught the contents of the selected procedure. This clinical-care procedure is frequently carried out in hospital care practices. Initially, the participation of students of the Basic Care subject was considered, who were beginning to develop technical skills during their first practice. However, the guide was designed for students of different semesters who face the healthcare procedure on a daily basis.

The thematic content was defined as a nursing care activity from the functional health patterns included in the diagnoses of the North American Nursing Diagnosis Association (13), in patterns such as Activity Exercise, Elimination and Nutritional Metabolic. This allowed us to conceptually support nursing care.

The learning spaces in which we worked were three: a) the classroom, b) technological means and c) the clinical simulation center. In the classroom, we developed the thematic content that justified, from the conceptual point of view, the realization of venipuncture. The technological means used were computers, tablets or smartphones to study the virtual guide, which allowed reinforcing the concepts learned in the classroom and preparing the simulated practice. At the clinical simulation center, the student practiced each step of the procedure repeatedly on task trainers in parts.

The analysis of the technological dimension comprised the thematic review of the contents taught in the classroom, which allowed generating the information architecture (14) 
based on the classification, content structuring, definition of general concepts, identification of equipment, procedure processes and verification, as can be seen in Figure 1. In each of these items we defined the scope and the learning objectives on what the student "should know," coupled with the possible interaction with what the student "should do," within the framework of the acquired skills. In the content matrix for the development of the virtual learning object (VLO), a list was made with the description of each topic, based on the students' multiple skills. Figure 2 shows the initial content matrix.

\section{Figure 1}

Information Architecture: "Guide for Venipuncture Procedures," first version.

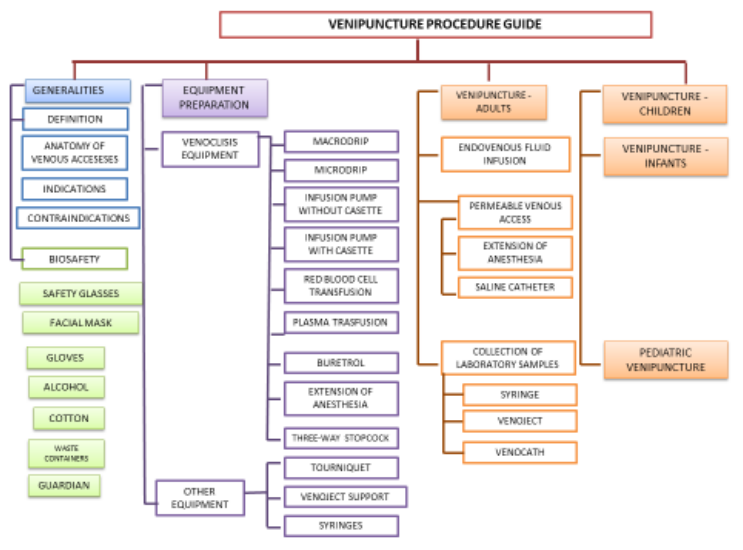

Figure 2

Content matrix for the development of the VLO proposed by the Centro Ático design team (2012).

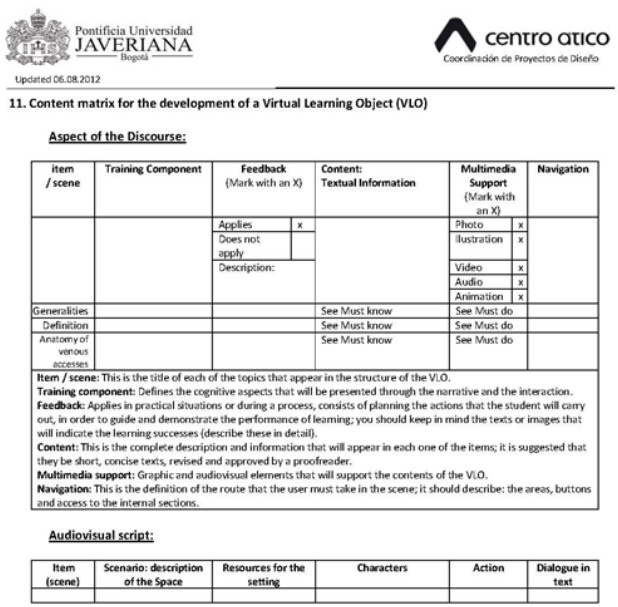

\section{Design}

From the pedagogical dimension, the design included elements from the behavioral and constructivist approaches, because knowledge and skills framed in observable and measurable learning objectives were taken into account (15), and the possibility of controlling own learning, mediated by the interaction with the technological resource included in the guide was increased (16).

The learning objectives consisted of: a) administering intravenous solutions, b) achieving permeable access routes, and c) taking samples for laboratory tests. The structure was built with a script that contained generalities, equipment and procedure. In the generalities dimension, aspects such as the definition of venipuncture, anatomy of vascular access, indications, contraindications, and aspects related to biosafety were taken into account. In the equipment dimension, an inventory of resources was carried out, among which were venous catheters, venoclysis equipment and syringes. In the procedure dimension, the literature was reviewed to find the scientific evidence in venous catheterization, to adjust the existing checklists, which contained the steps that were incorporated and supplemented for the procedure.

From the technological dimension, the design took into account the elements of the constructivist model, providing the student with the relevance of "building" his/her own knowledge, through the experience with the interaction of the learning contents. This learning environment leads to the creation of cognitive schemes through the assimilation of concepts and an approach to processes (15).

When defining the learning objectives, selecting the thematic concepts and creating the list of the equipment and the processes set out in the previous "Analysis" stage, methodological strategies were established within the framework of the creation of a constructivist learning environment leading to the understanding of the contents and the verification of the processes. 
Graphic and interactive representations of the venipuncture procedure were created to promote the approach to significant experiences in the context of the clinical simulation center; this allowed to build knowledge in a collaborative way through applicable digital media and technological formats. In this way, with the content matrix (Figure 2) all the thematic axes were listed and the dynamics of interaction for the students were identified; each item was defined with multimedia elements (17), and an inventory of graphic and audiovisual resources was generated, among others (Figure 3).

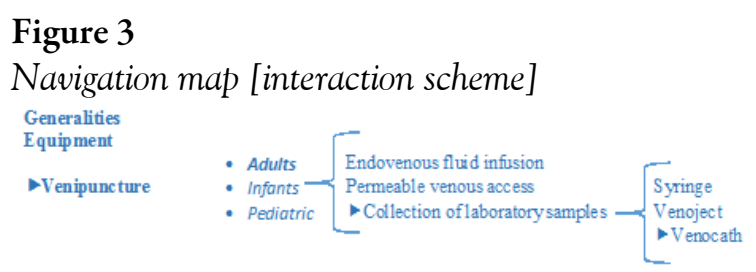

Likewise, a scheme was created that defined the interconnection of the thematic contents, relating concepts and procedures, which offered the students the possibility of deciding the sequence of information, deepening, rhythm of learning, and a relation with the contents.

Next, the navigation levels were outlined, configured by hierarchy of the information analyzed in the previous stage. In this sense, a multimedia container or web application was designed that connected the digital thematic contents and the students' learning experience. Graphic interaction elements were used, such as hyperlinks and user interface (UI) design (18); this latter is the relationship of the graphic appearance of the software (web application) with the user (student) interaction. Such interface was designed with a usability approach, so that it allowed to achieve the learning objectives in an imperceptible way; in other words, the nursing students found theoretical concepts and didactic exercises to understand the contents and in some cases obtain feedback, which led to a comprehensible and intuitive user experience.

There was a close relationship between the user interface (UI) design and the user experience (UX) design. The UX design tries to model the experience to use the product, which in this case is the web application; this involved knowing and analyzing the user: who he/she is, why and in what conditions he/she will use the application. "The objective of the interaction design is to create products that allow the user to reach his/her objectives in the best possible way" (19).

For the graphic pattern or interface design (Figure 4), we proposed the treatment of a stylized and schematic image, a photographic quality with optimal lighting and detail among its elements, together with the palette of fresh colors, concerning the clinical environment. In this way active or sensitive zones were created on the images that display information, to establish a virtual relationship between the elements and the practices.

\section{Figure 4}

Design of the graphic interface of the Guide for Venipuncture Procedures

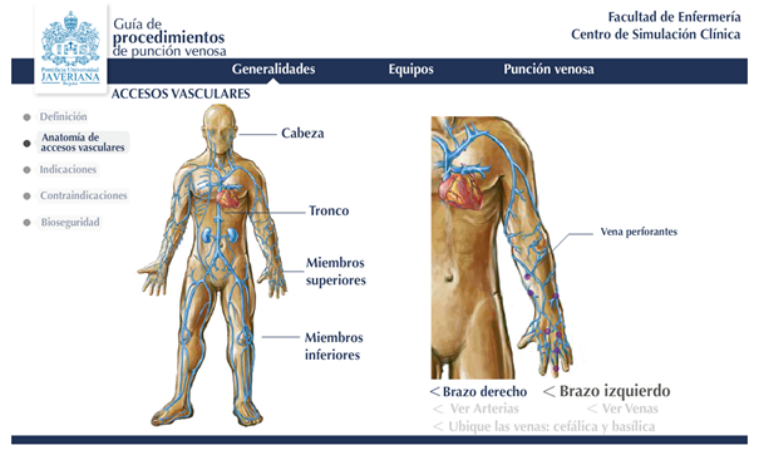

\section{Development}

Once we had the pedagogical approach and the design of the content structure, we proceeded to develop the materials. We took into account the textual explanation of each conceptual section, represented graphically and reviewed through a rapid and simple test, called Verification of the Process. The texts were written based on the contents of the guide, where each concept was described, which was supported by theoretical references explaining the scientific knowledge for nursing care in the execution of the procedure. The graphic representation took into account a resource inventory, according to the sequence 
of the thematic contents. In terms of process verification, interactivity was incorporated into the guide through games that linked videos, selfassessment tests and case selection.

The development of the technological dimension took into account that each thematic item would be represented by a digital product, framed in a graphic pattern applied to all the elements of the project (Figure 5). The theoretical bases were represented by an interactive content supported with illustrations, photographs and videos. The learning processes were verified as didactic activities and, in some cases, playful, where the student solved situations of case studies. Likewise, the clinical procedures were registered under an audiovisual production and post-production deployment.

\section{Figure 5}

Audiovisual presentation of the Guide for Venipuncture Procedures

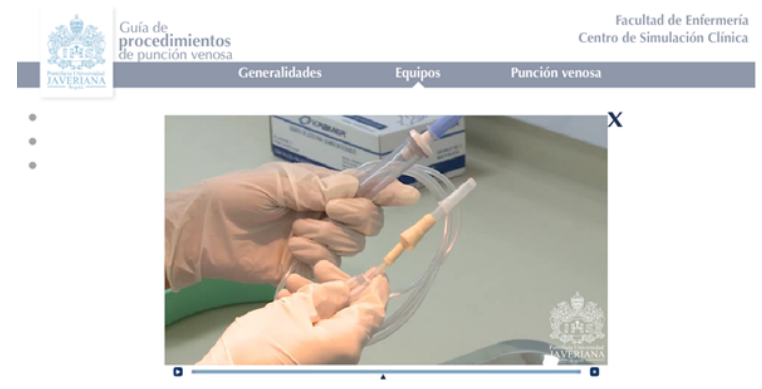

To develop the web application and the complementary digital content, we started with a production design, in which we considered the resource inventory defined in the design phase and the schedule based on production times. With a design team and audiovisual media experts, we proceeded to create the graphs for the user interface based on the script, the identification of the scenes for the visual record, and the venipuncture procedures. The web application was developed in Action Script 3.0 language, which allows to create complex interactivity, control of audiovisual reproduction and visualization of digital contents (20).

Additionally, we used an illustration, drawing and photography software to create three illustrations for the item Anatomy of vascular accesses: the human body and the vein and artery circulation system. From the graphic record, we selected 25 photographs of the venoclysis equipment and scenes from the physical space at the Clinical Simulation Center, made with a high-end camera and spot lighting. We recorded 12 audiovisual contents that consisted of 3 moments of venipuncture: preparation, purge and procedures. In addition, we recorded the use of biosecurity barriers, hand hygiene and waste disposal, among others. This audiovisual record was made with professors executing the processes. The narration was later recorded in an audio studio. The audiovisual equipment were high-end cameras that incorporate lights for filming and television. This recording took approximately 20 hours. In the post-production, the audio was edited and synchronized. After finishing the graphic and audiovisual elements, content was incorporated into the web application under planned programming parameters (Figure 6).

\section{Figure 6}

Presentation of the Guide for Venipuncture Procedures

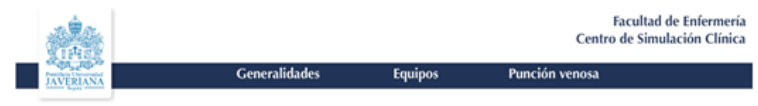

\section{Guía de} procedimientos de punción venosa

\section{Implementation}

Starting with the pedagogical dimension in the implementation phase, the students were allowed to review the didactic material in the Learning Manager System (LMS) virtual platform, in which they studied the thematic contents and consulted the videos that showed the modeling of the procedure; at the same time, when interacting, the learned process 
was verified. Next, the students attended the Clinical Simulation Center to practice with the technological support media, among which were computers, tablets, puncture materials and task trainers in parts.

As part of the learning self-verification, the students - after giving an informed consentwere filmed in the execution of the procedure, to contrast the executed steps in the audiovisual material, compared with the steps proposed in the virtual guide, in order to determine critical and control points to build learning, correct mistakes and seek excellence and clinical safety.

Teacher support from the feedback was continued after the learning self-verification. There, both, teacher and student, reviewed the steps to identify mistakes and adjust the process.

From the technological dimension, the implementation allowed to administer the contents, to put into practice the training action with the participation of the students, and to monitor the learning process.

The web application was hosted in a University network environment under LDAP (Lightweight Directory Access Protocol), which means that only the students and professors of the School of Nursing were allowed access. In turn, this information is provided through the LMS platform, based on the licenses administered by the University for students who take courses of the clinical component.

\section{Evaluation}

The evaluation phase corresponds to the presentation of results that allowed to verify the learning of the guide using virtual mediation. From the pedagogical dimension, the verification checklists and the perception of the students were analyzed.

A classroom research related to the application of checklists to verify learning had as unit of observation 159 participants distributed in four academic periods between 2015 and 2016. Table 2 shows the distribution of the primary statistics by academic period.
Table 2

Distribution by academic period

\begin{tabular}{|l|r|r|r|r|r|}
\hline & 2015-1 & 2015-2 & 2016-1 & 2016-2 & Average \\
\hline Mean & 4.12 & 3.97 & 4.10 & 3.76 & 3.99 \\
\hline Median & 4.20 & 4.40 & 4.30 & 3.75 & $\mathbf{4 . 1 6}$ \\
\hline Mode & 4.70 & 5.00 & 4.30 & 4.40 & $\mathbf{4 . 6 0}$ \\
\hline $\begin{array}{l}\text { Standard } \\
\text { deviation }\end{array}$ & 0.84 & 1.10 & 0.58 & 0.90 & $\mathbf{0 . 8 6}$ \\
\hline $\begin{array}{l}\text { Sample } \\
\text { variance }\end{array}$ & 0.70 & 1.22 & 0.34 & 0.81 & $\mathbf{0 . 7 7}$ \\
\hline Range & 3.70 & 4.00 & 2.60 & 4.70 & 3.75 \\
\hline Minimum & 1.30 & 1.00 & 2.30 & 0.30 & $\mathbf{1 . 2 3}$ \\
\hline Maximim & 5.00 & 5.00 & 4.90 & 5.00 & $\mathbf{4 . 9 8}$ \\
\hline $\begin{array}{l}\text { Total number } \\
\text { of students }\end{array}$ & 33 & 38 & $\mathbf{5 0}$ & 38 & $\mathbf{1 5 9}$ \\
\hline \multicolumn{5}{|l|}{ Source: Own preparation. } \\
\end{tabular}

The average score of the virtual guide was 3.99, which represents a negative asymmetry, because the mode was higher than the median, due to the influence of the concentration of high grades in the data distribution. Regarding the statistical range (maximum and minimum), the statistical range average was 3.75 , for the 159 students evaluated.

Between 2015 and 2016, nursing students conducted a research called: Perception of Nursing Students of the Pontificia Universidad Javeriana about the Use of the Virtual Guide for Venipuncture Procedures as a Learning Strategy. This research assessed the following dimensions: satisfaction, realistic clinical experiences, confidencemotivation, technical skills and decision-making (21). The dimension Realistic clinical experiences obtained the highest score, due to the connection between technical and practical knowledge and that it allowed to develop skills in the execution of several clinical procedures. On the other hand, the satisfaction dimension obtained the lowest score, due to factors such as teaching support, time management and availability of materials in the simulation center. The results show a good perception of the students on learning based on the virtual guide; they consider it practical, because it favors autonomy and strengthens the theoretical component. Communication was presented as a negative aspect, because the guide lacks this component to develop this skill.

Studying with the virtual guide satisfies and stimulates learning needs, because it motivates autonomy, is easy to understand, incorporates 
steps similar to the real procedure, and contains images and explanatory videos. Teacher support was considered an important aspect, because it favors the development of operational skills, creates confidence to attend clinical practice and complements the material studied in the classroom.

Regarding the technological dimension, in the evaluation phase there were problems to visualize the virtual guide, because the browsers used by the students should have an updated Flash application. At the time of using the virtual guide in 2010, Apple banned Flash in iPhones and iPads, and the web application created in the Action Script 3.0 language used Flash Player, Addobe Systems (19). This led to subsequent virtual guide building projects to identify the most popular browsers among students in new websites. Google Chrome is one of the favorites, for its stability; likewise, "Google designated HTML5 as the preferred Rich Media option in its Chrome browser through Flash Player" (20), which implies reading new websites in Hypertext Markup Language (HTML5), another programming language adaptable to mobile devices. These two languages have allowed to create multimedia material with similar interactions.

\section{Discussion}

The application of the instructional design model (ADDIE) in the construction of a virtual guide has showed satisfactory results. Analyzing, designing, developing, implementing and evaluating activities require time and dedication, in addition to having clear objectives that must be developed to achieve a better learning.

In 2008, the United Nations Educational, Scientific and Cultural Organization (UNESCO) created the information and communications technology (ICT) competency standards for teachers, which were assumed by Colombia in 2013. A pentagon of skills was identified related to: a) teaching, b) research, c) communication, d) management and e) technology; the latter is defined as the ability to "select and use a variety of technological tools in a relevant, responsible and efficient manner, understanding the principles that govern them, the way to combine them and the licenses that protect them" (22). The skills are expressed in degrees of complexity that correspond to exploration, integration and innovation.

The exploration level is generated when the teacher approaches the knowledge that allows him to conceptually elaborate the idea. The second level of integration is characterized by the fact that appropriate knowledge allows solving problems in specific contexts. This is followed by the innovation level, where there is an emphasis on creating, going beyond what has been learned and imagining novel explanations or significant actions (23).

These elements proposed by UNESCO correspond to ADDIE model stages, where the teachers identified the environment, raising the training needs. That exploratory level helped to establish the pedagogical approach to sequentially organize those harmonic contents with the instructional process with which it was intended to support a significant and autonomous learning; therefore, the use of an ICT could promote and stimulate a higher-level complex thought in the students.

Góngora and Martínez (5) point out that preparing professionals capable of using tools to efficiently create good-quality didactically coherent training materials requires training the learning designer, a role defined in educational software development teams. These authors conclude that learning models based on constructivist theories are adequate for modern educational contexts, as they offer better opportunities to design training actions and to develop professional skills. According to this, in order to creatively impact the teachinglearning process, ICTs should be used in line with overcoming challenges in the environments where the knowledge-based society has been established.

Robinson and Dearmon (24) consider that learning design requires some stages with defined tasks and results. For example, in the analysis 
stage, the task will be to assess the needs, identify the problem and analyze the tasks in order to establish a student profile. At the design stage, the process will consist of specifying how to learn after identifying the objectives, developing the topics and establishing an instructional plan, which requires establishing measurable objectives, specifying a prototype and defining the instructional strategy. Regarding the development stage, it is necessary to establish the process for the authorization and production of the material; therefore, at this stage the work is carried out with the producers, and scripts, organizational charts and work plans are developed; practical exercises are established and learning environments are created, because the instruction can be in a computational system that includes feedback, measurement and collaborative learning instruments. The implementation stage is the process of installing the project within the educational context, where the teacher receives a pilot training to verify the student's comments and generate evaluation data. Finally, in the evaluation stage, where the instruction is adapted, time records are needed, interpretation of evaluation results, and the recommendations obtained are parameterized.

The experience of applying the ADDIE instructional model to the creation of a virtual guide involved conceptualizing each of its stages. The implementation, for example, required executing what had been programmed in a didactically constructed format so that the learning was pleasant, and the evaluation required several moments to determine the results of the training action with the students. Therefore, the perception for the management of the guide was assessed and favorability was found to develop autonomy and theoretical apprehension. Apparently, the virtual guide stimulates learning and satisfies the students, because they find answers to their questions and the operational skill is strengthened. The ADDIE model has proven to be a useful instructional model for preparing traditional teaching materials, as there is an important intention to use this model in electronics and generate materials for online teaching (25).

Frota et al. (3) conducted a study on the construction of a technological education to teach peripheral venipuncture to nursing students, based on virtual learning environments. They concluded that the use of new ICTs facilitates instruction, as long as an interactive distance perspective is used and time is spent learning with new experiences. Technological resources illustrate nursing procedures, which makes it easier for students to easily accept instruction; therefore, learning is more effective. Videos, hyperlinks, images and hypertext were used in the research to present information, which improved learning, because the concepts were structurally associated. The results also showed that the participants considered positive to use virtual learning environments, since these create new possibilities to keep information and communication channels open. In turn, the study showed that the guide did not support any learning process regarding communication between the student and the patient, since the intention was the significant learning of a clinical-care procedure.

Some mistakes were made in the design of the guide, which were promptly corrected. For example, the use of images and trademarks belonging to various economic sectors, a situation that generated learning in this aspect and required a structural redesign, to avoid copyright problems. The implementation of the guide required significant financial support, given that this type of projects require technological elements with limited availability; in addition, trying to demonstrate that virtual education is as important as classroom and traditional education generates a cognitive dissonance in the university directors whose structural vision is centered on the administration and optimization of resources.

In our experience the evaluation was very interesting, because it required a permanent assessment by cohorts and academic periods; in addition, we made a qualitative and quantitative assessment of the perception of the use of this system, pointing out that in the programming phase the teacher plays the prominent role, 
and in the practice phase the student plays the prominent role. Dillard et al. (26) state that there are no standard methods to assess clinical simulation; therefore, it is important to have strategies to evaluate tasks, establish nursing roles and strengthen clinical judgment.

When comparing this experience with some studies, we found that the students' perception is positive in the acquisition of skills, in the participants' knowledge and attitudes; this improves the overall vision of the health problem and it is prioritized, especially when learning is combined with the simulated scenarios with which clinical-care procedures are practiced. This was demonstrated by Juguera Rodríguez et al. (27) in a clinical simulation study as a training tool.

In another study, Niño et al. (28) found that more than $90 \%$ of the students recognized that with clinical simulation significant learning is achieved and skills are strengthened, which makes them feel confident. Therefore, the creation of simulation guides helps to increase skills in a systematic way. In this regard, Curl et al. (29) reported that simulation should be part of the nursing curriculum from the first semesters, to better train students in care practices.

The ADDIE instructional model allows to create virtual guides of clinical-care procedures applying constructivist theory. This theory is very appropriate in modern educational contexts, because it offers better opportunities to design training actions and, with this, establish some professional skills. In this regard, Góngora and Martínez (5) have pointed out that the students use their knowledge better in changing and new situations if teaching is based on models that apply and solve problems, and learning design is a timely and optimal guidance to meet the educational needs. Likewise, these authors have identified that taking advantage of ICTs is crucial for teachers to use creative tools in teaching and learning processes, which is very relevant in the development of the knowledge-based society.

It is clear that part of the development of a virtual guide requires incorporating an instructional design model, whose main characteristic is behaviorism, since the contents are rigorously selected and made available to the student using didactics and VLOs for interaction; meanwhile, its presentation has graphics and sound, and it is incorporated into multimedia. The purpose of these resources it that the student has a programmed and systematic contact with contents and learning proposals that take him from simple to complex.

Luzardo, cited in Londoño (30), states that instructional design models used in virtuality, built with cognitive, behavioral and constructivist learning approaches, are those that best adapt to these learning environments, especially because they behave as open systems that exchange information with the environment where they are used. However, the constructivist instructional design incorporated in virtual education is not easy to develop, because "it must offer the student the possibility to choose different paths to reach knowledge" (30).

The teacher support process requires identifying the learning needs and exercising a responsible pedagogical practice with which interest, enthusiasm and motivation are transmitted, based on effective communication. On the other hand, autonomous learning is established when the student reflects critically on a process or procedure with which he/she chooses the best action based on knowledge. Thus, teaching support and autonomous learning are complementary processes that influence the participant' satisfaction, which is even increased when both are executed harmonically in an academic environment, especially in clinical simulation to learn assistance processes.

\section{Conclusion}

The results of the present teaching experience indicate that learning using a virtual guide provides a great opportunity to generate knowledge; however, its construction unquestionably requires an application method that in this case was the ADDIE model, which showed its relevance and favorability. 


\section{References}

1. Piña-Jiménez L, Amador-Aguilar

R. La enseñanza de la enfermería con simuladores, consideraciones teórico-pedagógicas para perfilar un modelo didáctico. Enferm Univ. 2015;12(3):152-9.

2. Díaz JL, Leal C, García J, Hernández E, Adáñez M, Sáez A. SelfLearning Methodology in Simulated Enviroments (MAES): Elements and caracheristics. Clin Simul Nurs. 2016; (12):268-74.

3. Frota NM, Barros LM, Araújo TM, Caldini LN, Nascimento JC, Caetano JA. Construction of an educational technology for teaching about nursing on peripheral venipuncture. Rev Gaúcha Enferm. 2013;34(2):29-36.

4. Coll C. Psicología de la educación y prácticas educativas mediadas por las tecnologías de la información y la comunicación: una mirada constructivista. Revista Electrónica Sinéctica [Internet]. 2004 ago-ene [Cited 2018 Jun 15]. Avalaible from: http://www.redalyc.org/articulo. oa? $\mathrm{id}=99815899016$.

5. Góngora Parra Y, Martínez Leyet OL. Del diseño instruccional al diseño de aprendizaje con aplicación de tecnologías: teoría de la educación. Educación y Cultura en la Sociedad de la Información [Internet]. 2012 [cited 2018 Jun 15];13(3):343-60. Avalaible from: http://www.redalyc.org/articulo. oa? $\mathrm{id}=201024652016$.

6. Hsu T, Lee-Hsieh J, Turton M, Cheng S. Using the ADDIE Model to develop online continuing education courses on caring for nurses in Taiwan. J Contin Edud Nurs. 2014;45(3):124-31.

7. Acevedo F, Díaz J, Cobo J. Efectividad en el aprendizaje de la punción venosa en estudiantes de enfermería utilizando dos estrategias didácticas: "Una experiencia investigativa en aula." Investig Enferm Imagen Desarr. 2016;18(2):61-75.

8. Galindo Z. Percepción de los estudiantes de enfermería de la Pontificia Universidad Javeriana sobre el uso de la simulación clínica como estrategia de aprendizaje [thesis degree] [internet]. Bogotá: Pontificia Universidad Javeriana; 2013 [cited 2018 Jun 15]. Avalaible from: http://repository.javeriana.edu.c o/bitstream/10554/13763/1/GalindoZa mbranoCarolAndrea2013.pdf

9. Gamboa D, Pérez M, Martínez S. Percepción de los estudiantes de enfermería de la Pontificia Universidad Javeriana sobre el aprendizaje a través de la simulación clínica [thesis degree] [internet]. Bogotá: Pontificia Universidad Javeriana; 2013 [cited 2018 Jun 15]. Avalaible from: http://repository.javeriana.edu.c o/bitstream/10554/13761/1/GamboaM ahechaDianaPatricia2013.pdf

10. Botero M, López P. Percepción de los estudiantes de enfermería de la Pontificia Universidad Javeriana sobre el uso de la simulación clínica como estrategia de aprendizaje [trabajo de grado] [internet]. Bogotá: Pontificia Universidad Javeriana; 2011 [cited 2018 Jun 15]. Avalaible from: http://repository.javeriana.edu.c o/bitstream/10554/9681/1/tesis19-9.pd $\mathrm{f}$

11. Moreno J, Salazar E, Solorza J. Adherencia de los estudiantes a las guías de procedimientos en simulación clínica para el aprendizaje en enfermería [trabajo de grado] [Internet]. Bogotá: Pontificia Universidad Javeriana; 2014. Avalaible from: http://repository.javeriana.edu.c 
o/bitstream/10554/13812/1/MorenoRo jasJesikaLorena2014.pdf

12. Neva D, Malagón J, Rojas C. Adherencia de los estudiantes a las guías de procedimientos en simulación clínica para el aprendizaje en enfermería [thesis degree] [Internet]. Bogotá: Pontificia Universidad Javeriana; 2014 [cited 2018 Jun 15]. Avalaible from: https://re pository.javeriana.edu.co/bitstream/ha ndle/10554/16396/NevaRaquiraDeisy Mayerly2014.pdf? sequence $=1$ \& isAllo wed $=\mathrm{y}$

13. Herdman T, Kamitsuru, S. Diagnósticos enfermeros: definiciones y clasificación 2015-2017. Barcelona: Elsevier; 2015.

14. Rosenfeld L, Morville, P. Information architecture for the World Wide Web. Vol. 3. 3rd ed. Beijing: O'Reilly; 2006.

15. Sáez J. La práctica pedagógica de las tecnologías de la información y la comunicación y su relación con los enfoques constructivistas. REICE [Internet]; 2012 [cited 2018 Jun 15]. Avalaible from: http://www.redalyc.org /articulo.oa?id=55123361005

16. De León I, Suárez J. El diseño instruccional y tecnologías de la información y la comunicación: posibilidades y limitaciones. Rev Investig [Internet]. 2008 [cited 2018 Jun 15]. Avalaible from: http://www.redalyc.org/articulo. oa? $\mathrm{id}=376140380003$

17. Gertrudix M, Fernández M, Álvarez S. Metodología de producción para el desarrollo de contenidos audiovisuales y multimedia para MOOC. Revista Iberoamericana de Educación a Distancia. 2017;20(1):183-203.

18. Oh J, Moon N. Towards a cultural user interface generation principles. Multimedia Tools Appl. 2013;63:195-216.

19. Bergstrom J, Schall A. Eye tracking in user experience design. Waltham, MA: Elsevier; 2014.

20. Lundin L. Web design. Salem Press Encyclopedia [serial on the Internet]; 2013 [cited 2018 Jun 15]. Research Starters.

21. Jaime D, Rodríguez R, Robayo D, Mojica Y. Percepción de los estudiantes de enfermería de la Pontificia Universidad Javeriana sobre el uso de la Guía de Procedimiento Virtual en Punción Venosa como Estrategia de Aprendizaje [trabajo de grado] [Internet]. Bogotá: Pontificia Universidad Javeriana; 2016 [cited 2018 Jun 15]. Avalaible from: https://re pository.javeriana.edu.co/bitstream/ha ndle/10554/21091/JaimeBuitragoDian aCarolina2016.pdf? sequence $=1$ \& is All owed $=\mathrm{y}$

22. Organización de las Naciones Unidas para la Educación, la Ciencia y la Cultura (Unesco). Estándares de Competencia en TIC para docentes [Internet]; 2008 [cited 2018 Jun 15]. Avalaible from: http://eduteka.icesi.edu.co/ pdfdir/

UNESCOEstandaresDocentes.pdf

23. Ministerio de Educación Nacional Colombia. Competencias TIC para el desarrollo profesional docente [Internet]. Bogotá: Ministerio; 2013 [cited 2018 Jun 15]. Avalaible from: https://www.mineducacion.gov.c o/1759/articles-339097_archivo_pdf_c ompetencias_tic.pdf

24. Robinson BK, Dearmon V. Evidence-based nursing education: effective use of instructional design and simulated learning environments to enhance knowledge transfer in undergraduate nursing students. J Prof 
Nurs. 2013;29(4):203-9. https://doi.org /10.1016/j.profnurs.2012.04.022

25. Drljača D, Latinović B, Stanković Z, Cvetković D. Addie model for development of e-courses. Documento procedente de la International Scientific Conference on Information Technology and Data Related Research SINTEZA [Internet]; 2017 [cited 2018 Jun 15]. Avalaible from: http://portal.sinteza.singidunum. ac.rs/Media/files/2017/242-247.pdf

26. Dillard N, Sideras S, Ryan M, Carlton K, Lasater K, Siktberg L. A collaborative project to apply and evaluate the clinical judgment model through simulation. Nurs Educ Res. 2009;30(2):99-104.

27. Juguera Rodríguez L, Díaz Agea J, Pérez Lapuente ML, Leal Costa C, Rojo Rojo A, Echevarría Pérez P. La simulación clínica como herramienta pedagógica: percepción de los alumnos de Grado en Enfermería en la UCAM (Universidad Católica San Antonio de Murcia). Enferm Global [internet]. 2014 [cited 2018 Jun 15];33:175-90. Avalaible from: http://scielo.isciii.es/pd f/eg/v13n33/docencia3.pdf

28. Niño $\mathrm{C}$, Vargas $\mathrm{N}$, Barragán J. Fortalecimiento de la simulación clínica como herramienta pedagógica en enfermería: experiencia de internado. CUIDARTE [internet]. 2015 [cited 2018 Jun 15];6(1):970-6. Avalaible from: https://www.revistacuidarte.org/i ndex.php/cuidarte/article/view/161

29. Curl E, Smith S, Chisholm L, McGee L, Das K. Effectiveness of integrated simulation and clinical experiences compared to traditional clinical experiences for nursing students. Nurs Educ Perspect [internet]. 2016 [cited 2018 Jun 15];37(2):72-7. Avalaible from: https://scholarworks.waldenu.ed $\mathrm{u} /$ cgi/viewcontent.cgi? referer $=\&$ https redir $=1 \&$ article $=2462 \&$ context $=$ dis sertations

30. Londoño E. El diseño instruccional en la educación virtual: más allá de la presentación de contenidos. Revista Educación y Desarrollo Social. 2011;6(2):112-7. 